\title{
Sistem Informasi Penjualan Ayam Potong pada Peternakan Ayam Surya Putra Broiler
}

\author{
Budhi Sumboro*1, Paryanta $^{2}$, Devito Surya Wicaksana ${ }^{3}$ \\ ${ }^{13}$ Program Studi Sistem Informasi; ${ }^{2}$ Program Studi Teknik Komputer; \\ ${ }^{123}$ STMIK AUB Surakarta, Indonesia \\ e-mail: *1budhi.sumboro@stmik-aub.ac.id, ${ }^{2}$ paryanta@stmik-aub.ac.id, ${ }^{3}$ devitos@gmail.com
}

\begin{abstract}
Abstrak
Peternak Ayam Surya Putra Broiler adalah suatu badan usaha yang bergerak di bidang penjualan ayam potong mentah. Proses jual beli tersebut terdiri dari penjualan ke customer masih menggunakan nota manual penjualan. Untuk membantu proses transaksi penjualan di Surya Putra Broiler maka perlu dibuatkan Sistem Informasi Penjualan ayam potong mentah di peternakan ayam Surya Putra Broiler, yang dapat melakukan transaksi penjualan dan pengolahan laporan penjualan dengan lebih baik. Hasil perancangan sistem informasi penjualan ini menggunakan metode pengembangan sistem waterfall. Untuk analisa kelemahan sistem menggunakan analisa PIECES sedangkan untuk menggambarkan alur data menggunakan Unified Modeling Language. Bahasa pemrograman yang digunakan adalah Android Studio sedangkan untuk pengolahan database menggunakan MySQL. Berdasarkan pengujian yang telah dilakukan menggunakan blackbox testing, sistem yang dibangun dapat membantu masalah yang dihadapi pengelola Peternak Ayam Surya Putra Broiler.
\end{abstract}

Kata kunci: Peternakan Ayam Surya Putra Broiler, Sistem Informasi Penjualan, Android, $M y S Q L$

\section{PENDAHULUAN}

Studi Sistem informasi sangat dibutuhkan dalam suatu organisasi baik instansi pemerintah, instansi swasta maupun lembaga-lembaga sosial sebagai yang dapat mempermudah dalam proses memberikan informasi terutama dalam proses pengolahan data dan pembuatan laporan. Pemanfaatan tekhnologi smartphone android juga dapat mempermudah dalam mencari informasi yang diinginkan dan sebagai alat komunikasi tanpa mengenal jarak dan waktu.

Jika beberapa tahun lalu sistem informasi penjualan terbatas dalam bentuk desktop, kini sistem informasi penjualan juga sudah mulai dikembangkan pada perangkat mobile berbasis android. Android merupakan sistem operasi berbasis linux yang memang diperuntukan bagi smartphone maupun komputer tablet.

Hal ini cukup beralasan mengingat terdapat segudang kelebihan yang dimiliki aplikasi berbasis android. Dengan sistem informasi administrasi berbasis android, pengguna aplikasi dapat menggali informasi dimana saja dan kapan saja. Peternak Ayam Surya Putra Broiler adalah suatu badan usaha yang bergerak di bidang penjualan ayam potong. Perternakan ini beralamatkan Giriwondo, Jumapolo, Karanganyar. Adapun kegiatan utama yang di lakukan di peternak ayam Surya Putra Broiler adalah transaksi Penjualan Ayam. Proses jual beli tersebut terdiri dari penjualan ke customer. Sedangkan untuk proses penjualanya customer memilih barang yang akan dibeli, kemudian karyawan memberikan jumlah harga yang harus di bayarkan customer. Setelah Customer membayarkan jumlah harga kemudian karyawan membuatkan nota.

Berdasarkan permasalahan yang ada maka peneliti tertarik untuk membangun aplikasi, yang dapat digunakan dan mempermudah proses penjualan. untuk itulah peneliti 
memilih judul "Sistem Informasi Penjualan ayam potong pada peternakan ayam Surya Putra Broiler".

\section{METODE PENELITIAN}

\subsection{Analisis PIECES}

Untuk mengidentifikasi masalah, maka harus dilakukan analisis terhadap ekonomi, pengendalian, efisiensi dan pelayanan atau juga sering disebut dengan analisis pieces. Adapaun pengertian dari analisis pieces sebagai berikut Al Fatta (2007):

Tabel 1 Analisis PIESCES

\begin{tabular}{|c|c|}
\hline Analisa & $\begin{array}{c}\text { Yang sedang } \\
\text { berjalan }\end{array}$ \\
\hline $\begin{array}{l}\text { Perfomance } \\
\text { (Kinerja) }\end{array}$ & $\begin{array}{l}\text { pengolahan data masih dilakukan secara } \\
\text { manual yaitu dicatat dalam buku dan untuk } \\
\text { transaksi penjualan masih menggunakan } \\
\text { nota manual sehingga membutuhkan } \\
\text { waktu lebih banyak untuk merekap } \\
\text { laporan penjualan }\end{array}$ \\
\hline $\begin{array}{l}\text { Information } \\
\text { (Informasi) }\end{array}$ & $\begin{array}{l}\text { Informasi transkasi dapat dilihat dari nota } \\
\text { yang sudah terkumpul dan juga rekap } \\
\text { dibuku }\end{array}$ \\
\hline $\begin{array}{l}\text { Economy } \\
\text { (Ekonomi) }\end{array}$ & $\begin{array}{l}\text { Biaya yang dikeluarkan relative tinggi } \\
\text { karena harus membeli buku untuk rekap } \\
\text { penjualan dan nota untuk melakukan } \\
\text { transaksi penjualan. }\end{array}$ \\
\hline $\begin{array}{l}\text { Control } \\
\text { (Keamanan) }\end{array}$ & $\begin{array}{l}\text { Keamanan data-data sangat kurang, } \\
\text { karena data hanya disimpan didalam buku } \\
\text { tentu saja rentan dengan hilang atau rusak } \\
\text { karena sifat kertas yang mudah rusak. }\end{array}$ \\
\hline $\begin{array}{l}\text { Efficiency } \\
\text { (Efisiensi) }\end{array}$ & $\begin{array}{l}\text { Dalam pengerjaan transaksi penjualan } \\
\text { dan rekap penjualan ditulis kedalam buku } \\
\text { sehingga membutuhkan banyak waktu. }\end{array}$ \\
\hline $\begin{array}{l}\text { Service } \\
\text { (Layanan) }\end{array}$ & $\begin{array}{l}\text { Belum memberikan kemudahan dalam } \\
\text { pengerjaan pendataan barang dan laporan } \\
\text { penjualan barang. }\end{array}$ \\
\hline
\end{tabular}

\section{HASIL DAN PEMBAHASAN}

Dalam pembuatan aplikasi ini dibutuhkan suatu implementasi untuk menguraikan program dan analisis dari hasil program yang telah dibuat. Tujuan pembahasan ini adalah untuk mengetahui apakah program yang dibuat sudah bekerja seperti yang diharapkan atau belum. Berikut adalah proses pembahasan interface atau antarmuka program:

a. Antar muka halaman pemilik 


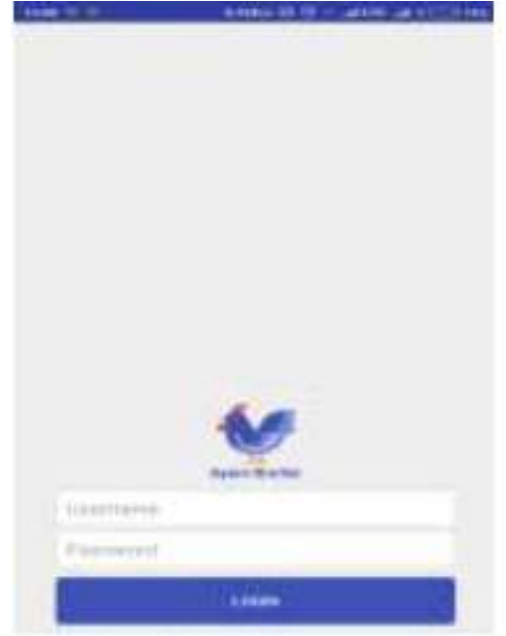

Gambar 1 Halaman Login Administrator

Pemilik harus memasukkan username dan password lalu klik tombol login. Jika username dan password benar maka sistem akan menampilkan halaman beranda admin.
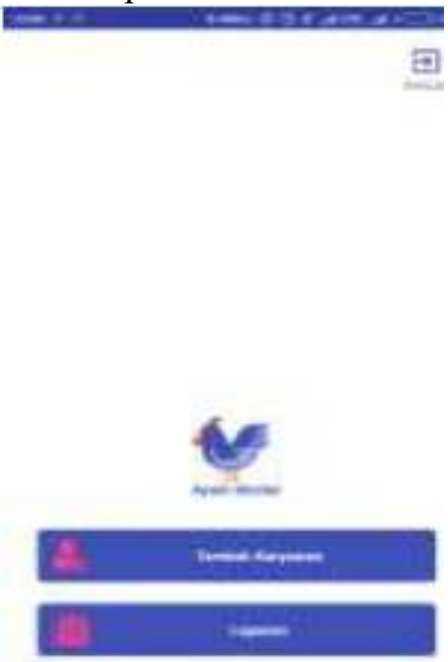

Gambar 2 Halaman Beranda Admin

Apabila proses login sudah berhasil, maka sistem akan menampilkan halaman beranda pemilik, menu yang akan di tampilkan pada beranda ada dua yaitu tambah karyawan untuk mengelola data karyawan dan laporan untuk mengelola laporan penjualan.

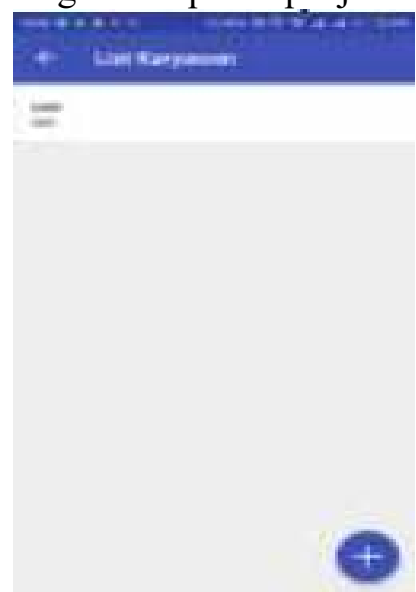

Gambar 3 Halaman Data Karyawan 
Halaman ini menampilkan data karyawan yang bekerja pada Surya Putra Broiler. Data karyawan ini yang berisi username dan password yang nantinya digunakan oleh karyawan untuk mengelola transaksi penjualan dan laporan penjualan. Pada halaman pojok kanan terdapat simbol $(+)$ yang digunakan untuk menambah data karyawan.

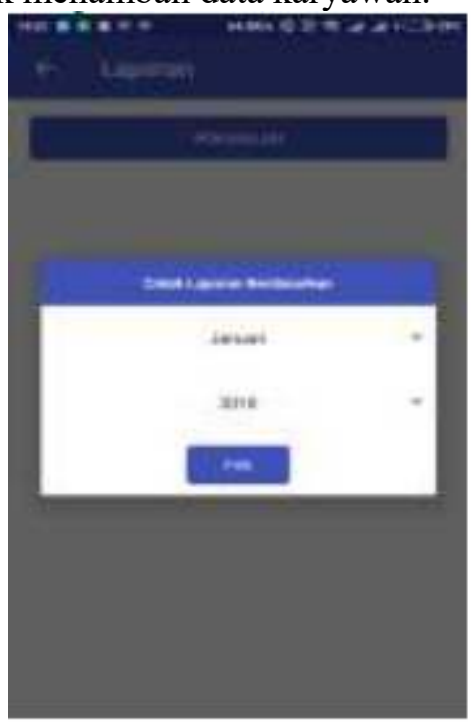

Gambar 4 Halaman Cetak Laporan Penjualan

Selanjutnya pemilik memasukkan periode bulan dan tahun yang ingin dilihat atau dicetak pada laporan penjualan yang ada di Surya Putra Broiler. Setelah di masukkan periode yang ingin ditampilkan kemudian klik tombol "pilih".

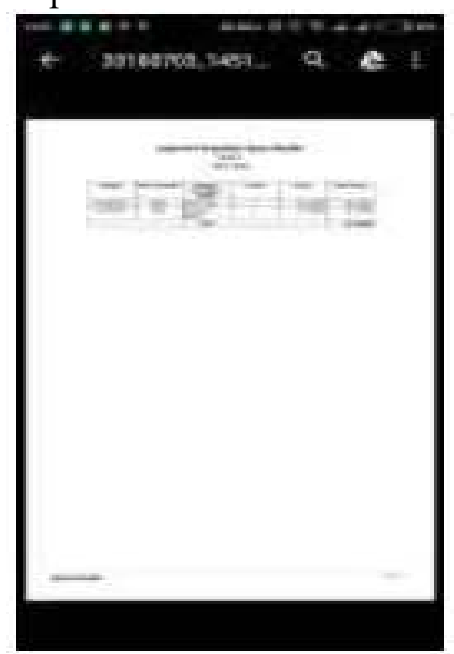

Gambar 5 Halaman Laporan Penjualan

Pada header terdapat judul dan bulan serta tahun penjualan, sesuai dengan periode yang sudah dimasukkan. Pada tabel dibawahnya terdapat tanggal, nama pembeli, kategori pembelian ayam (ayam mentah), jumlah (satuan kg), harga (per kg) dan total harga. Pada bagian bawah tabel tersapat jumlah total keseluruhan penjualan pada bulan tersebut.

b. Antar muka halaman pelanggan 


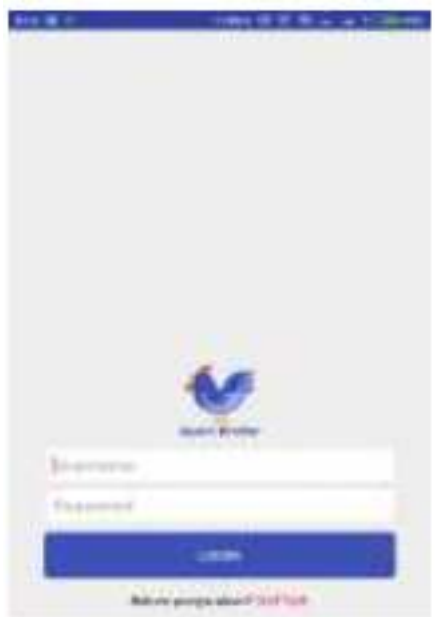

Gambar 6 Halaman Login Pelanggan

Setelah membuka aplikasi ayam broiler, selanjutnya pelanggan harus melakukan login kedalam sistem bagi yang sudah memiliki username dan password. Jika belum maka pelanggan harus melakukan register atau pendafatran pelanggan baru.

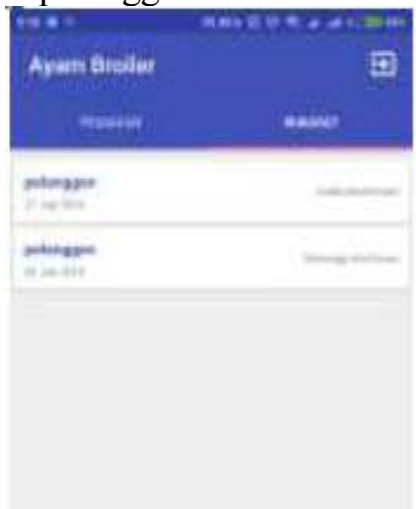

Gambar 7 Halaman Riwayat Pelanggan

Pada halaman riwayat pelanggan menampilkan data riwayat pemesanan secara online oleh pelanggan. Menampilkan informasi apakah pemesanan tersebut sudah dikonfirmasi atau belum.

c. Antar muka halaman karyawan 


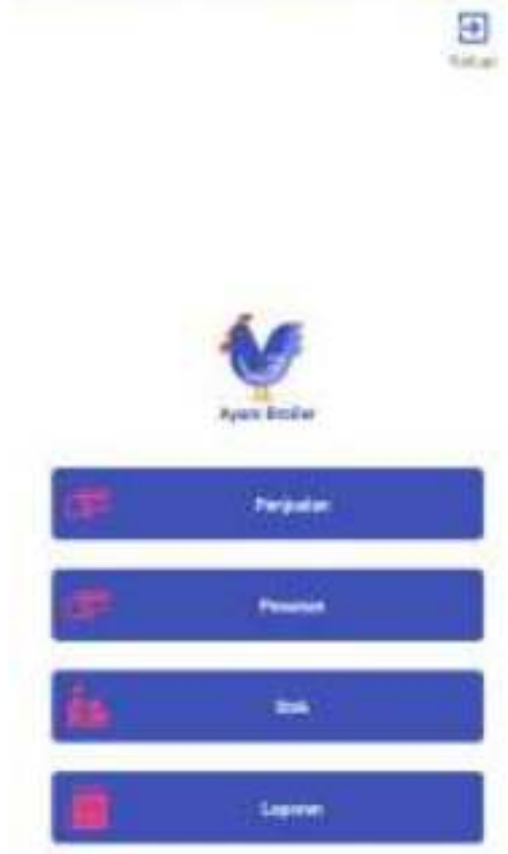

Gambar 8 Halaman utama karyawan

Halaman utama karayawan menampilkan pilihan menu penjualan, pesanan, stok dan laporan. Menu penjualan menampilkan informasi form penjualan secara offline. Menu pesanan menapilkan data pesanan yang dilakukan oleh pelanggan secara online. Menu stok berisi data stok dan menu laporan menampilkan data laporan.

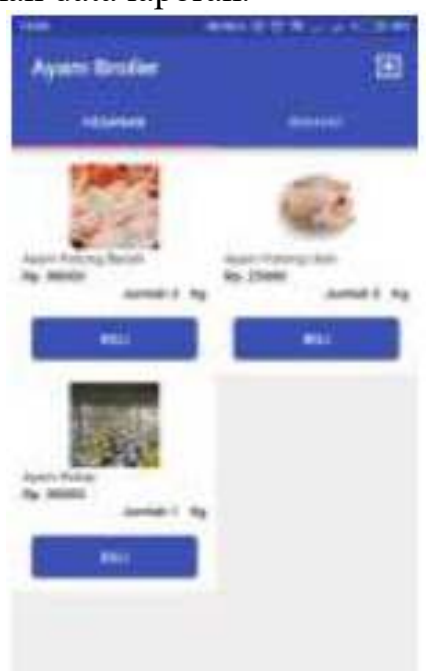

Gambar 9 Halaman Katolog Produk

Halaman list pemesanan menampilkan daftar pemesanan ayam secara online oleh pelanggan. Untuk mengkonfirmasi pesanan klik tombol konfirmasi. 


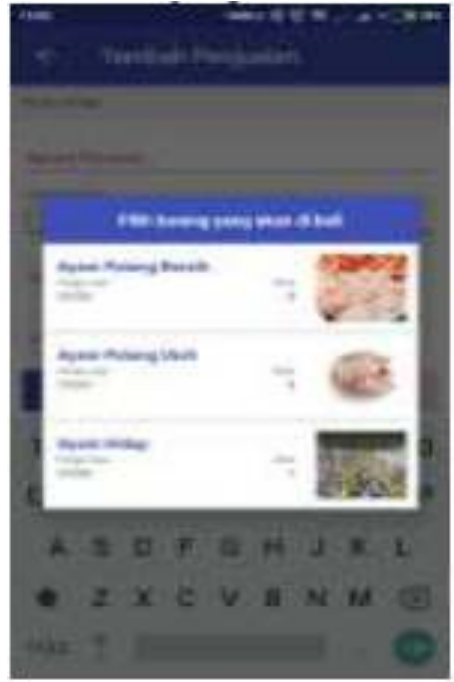

Gambar 11 Halaman tambah penjualan

Untuk memasukkan data transaksi penjualan, admin harus memasukkan data pelanggan yaitu nama pembeli, kategori ayam (ayam mentah), pada halaman harga akan otomatis terisi selanjutnya pilih tombol "Tambah" untuk menyimpan data transaksi penjualan, dan data tersebut akan tampil pada List Pembelian yang berada dibawah tombol "Tambah" dan "Pembayaran".

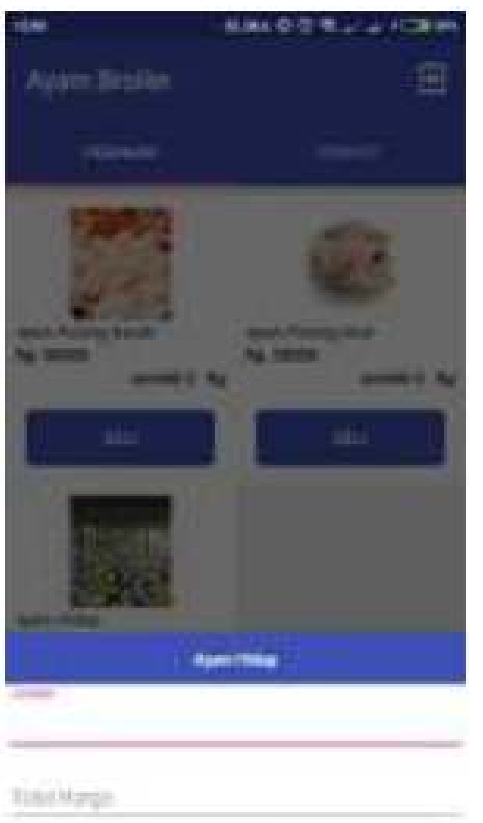

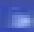

Gambar 12 Halaman detail pembelian

Halaman detail pembelian menampilkan pop up form yang berisi informasi jumlah ayam yang dibeli dan total harga akan muncul secara otomatis. Kemudian transaksi akan dilanjutkan ke halaman pembayaran. 


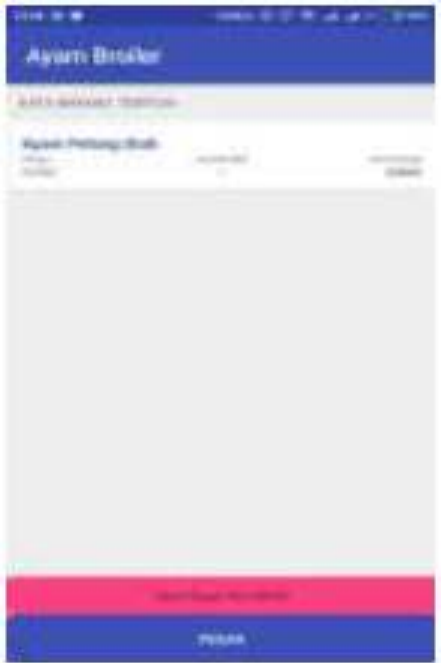

Gambar 13 Halaman Pembayaran

Pada halaman pembayaran terdapat informasi total bayar dan sisa bayar. Untuk memasukkan nominal pembayaran dari pelanggan ketikkan pada form total bayar dan aplikasi akan menampilkan sisa bayar atau kembalian kemudian pilih "Pesan" untuk menyimpan data transaksi tersebut.

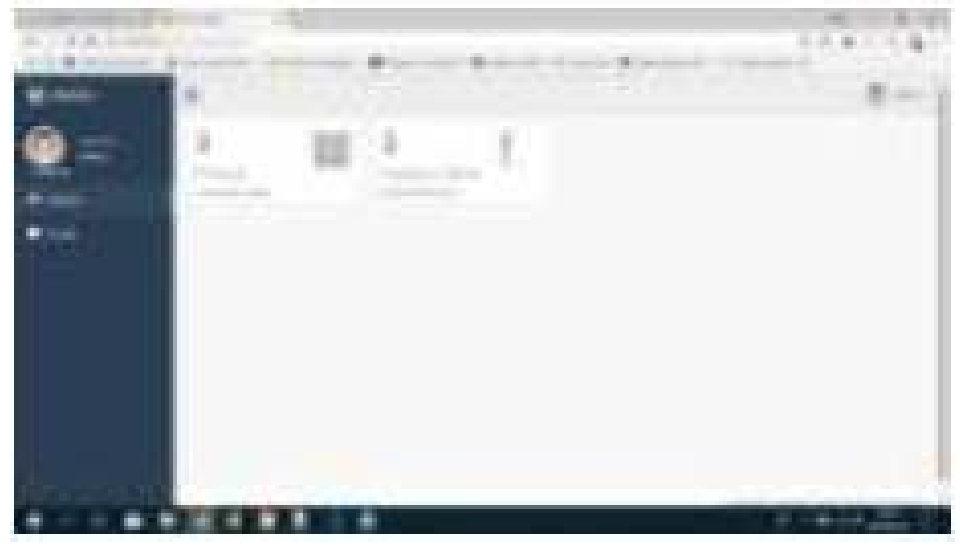

Gambar 14 Halaman admin

Halaman beranda admin, merupakan halaman untama admin setelah menjalankan web admin.

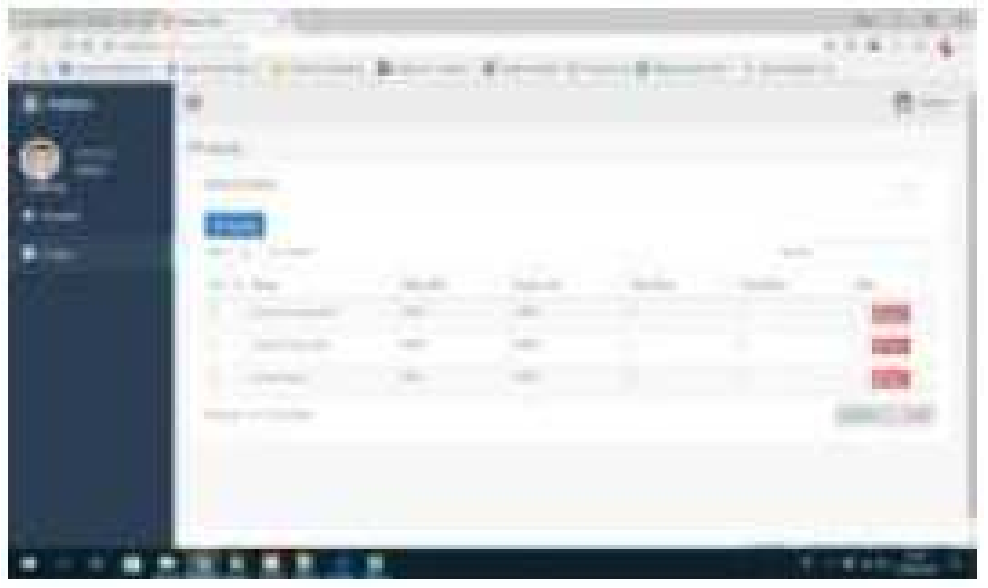

Gambar 15 Halaman data Ayam

Halaman data ayam menampilkan data ayam yang dimiliki oleh Surya Putra Broiler. Informasi yang ditampilkan yaitu nama produk, harga beli, harga jual, dan stok yang dimiliki. Untuk menambah data ayam +Tambah pada atas tabel dan hapus data pada kolom tabel. 


\section{KESIMPULAN}

Hasil perancangan Sistem Informasi Penjualan ayam potong pada peternakan ayam Surya Putra Broiler, menggunakan metode pengembangan sistem waterfall. Untuk perancangan proses terdiri dari flowchart, usecase diagram, activity diagram, sequence diagram, class diagram dan relasi antar tabel. Perancangan Sistem Informasi Penjualan ayam potong pada peternakan ayam Surya Putra Broiler menggunakan Bahasa pemrograman Android Studio. Sedangkan untuk pengolahan database menggunakan MySQL. Sistem Informasi Penjualan ayam potong pada peternakan ayam Surya Putra Broiler, digunakan sebagai media untuk mengolah data karyawan, melakukan transaksi penjualan serta mengelola laporan penjualan. Sistem Informasi Penjualan ayam potong pada peternakan ayam Surya Putra Broiler dilengkapi dengan fasilitas pemesanan secara online, yang diharapkan mamu menaikkan omset penjualan Surya Putra Broiler. Adanya sistem informasi penjualan ini diharapkan dapat mengurangi kinerja karyawan dalam pengelolaan transaksi dibantu dengan adanya sistem baru yang dapat diakses baik secara online dan offline.

\section{SARAN}

Sistem Informasi Penjualan ayam potong pada peternakan ayam Surya Putra Broiler Berbasis Android, masih dapat dikembangkan lebih lanjut, yaitu: menambahkan metode pembayaran pada aplikasi ataupun pembayaran via transfer ATM. Menambahkan laporan laba dan rugi setiap waktu yang sudah ditentukan. Dapat melakukan pembayaran melalui saldo atau e-money dan juga dapat memakai Go-Pay.

\section{DAFTAR PUSTAKA}

[1] Haryanto, Bambang. 2011:2. Esensi-esensi Bahasa Pemrograman Java. Yogyakarta: Andi.

[2] Jeffrey. L. Whitten, Lonnie D.Bentley, Kevin C. 2001. System Analysis and Design Methods 5thEd. McGraw-Hill.

[3] Jogiyanto. 2005. Analisis \& Deasin Sistem Informasi.:Pendekatan Terstruktur Teori dan Praktek Aplikasi Bisnis. Yogyakarta: Andi.

[4] Kristanto. 2003. Konsep dan Perancangan Basis Data. Yogyakarta: Andi.

[5] Ladjamudin, Al Bahra. 2005. Analisis dan Desain Sistem. Tangerang: Graha Ilmu

[6] Mulyanto, Agus. 2009. Sistem Informasi Konsep dan Aplikasi. Yogyakarta: Pustaka Pelajar

[7] Nugroho, Adi. 2006. E-commerce. Informatika Bandung.

[8] O’Brien, James A. 2006. Pengantar Sistem Informasi: Prespektif bisnis dan manajerial. Jakarta: Salemba Empat

[9] Pressman, Roger S. 2001.Rekayasa Perangkat Lunak Pendekatan Praktisi. Yogyakarta: Andi.

[10] Safaat, Nazruddin. 2012. Android Pemrograman Aplikasi Mobile Smartphone dan Tablet PC Berbasis Android. Bandung: Informatika Bandung.

[11] Shalahuddin, $M$ dan Rosa. 2015. Rekayasa Perangkat Lunak Tersruktur dan Berorientasi Objek. Bandung : Informatika.

[12] Sulhan dan Ely. 2008. Manajemen Bank Konvensional dan Syariah. Jakarta: PT. Raja Grafindo Persada Winardi. 2007. Motivasi dan Manajemen. Jakarta: PT. Raja Grafin 